\title{
Pipes and praxis: a methodological contribution to the urban political ecology of water
}

\author{
Lucero Radonic \\ Sarah Kelly-Richards ${ }^{1}$ \\ Michigan State University, USA \\ University of Arizona, USA
}

\begin{abstract}
This article contributes to the urban political ecology of water through applied anthropological research methods and praxis. Drawing on two case studies in urban Sonora, Mexico, we contribute to critical studies of infrastructure by focusing on large infrastructural systems and decentralized alternatives to water and sanitation provisioning. We reflect on engaging with residents living on the marginal hillsides of two rapidly urbanizing desert cities using ethnographic methods. In the capital city of Hermosillo, Radonic emphasizes how collaborative reflection with barrio residents led her to reframe her analytical approach to water governance by recognizing informal water infrastructure as a statement of human resilience in the face of social inequality, resource scarcity, and material disrepair. In the border city of Nogales, Kelly-Richards reflects on the outcomes of conducting community-based participatory research with technical students and residents of an informally settled colonia around the construction of a composting toilet, while also investigating municipal government service provision efforts. Our article invites readers to view these infrastructure alternatives as ways to explore how applied anthropology can advance the emancipatory potential of urban political ecology through a collaborative investigation of uneven urbanization and basic service provisioning. We emphasize everyday situated relationships with infrastructure in informally organized neighborhoods. Using praxis to collectively investigate the complex and entangled relations between large piped water and sanitation projects and locally developed alternatives in under serviced areas, the two case studies reveal lessons learned and illuminate grounded research openings for social justice and environmental sustainability.
\end{abstract}

Key words: Applied anthropology, infrastructure, political ecology, praxis, water governance, social justice

\section{Résumé}

Cet article contribue à l'écologie politique urbaine de l'eau, grâce à des méthodes de recherche anthropologiques appliquées, et praxis. Nous utilisons deux études de cas dans l'État de Sonora urbaine, au Mexique, à des études critiques de l'infrastructure. Nous nous concentrons sur les grands systèmes d'infrastructure et des alternatives décentralisées à la fourniture de l'eau et de l'assainissement. En utilisant des méthodes ethnographiques nous réfléchissons sur l'engagement avec les résidents, qui vivent sur les versants de deux villes du désert qui sont en voie d'urbanisation rapide. Dans la capitale de Hermosillo, Radonic souligne comment la réflexion de collaboration avec les résidents d'un barrio a l'amenée à recadrer son analyse de la gouvernance de l'eau. Elle a reconnu l'infrastructure de l'eau informelle comme une

\footnotetext{
${ }^{1}$ Dr. Lucero Radonic, Assistant Professor, Department of Anthropology, Michigan State University, East Lansing, MI 48824, USA. Email: radonicl "at" msu.edu. Sarah Kelly-Richards, Doctoral Candidate, School of Geography and Development, University of Arizona, Tucson, AZ 85719, USA. Email: shkelly "at" email.arizona.edu. The authors would like to acknowledge Diane Austin, Nikhil Anand, Carl Bauer, Jeffrey Banister, Thomas Sheridan, and Angela Storey for engaging conversations that influenced the formation of this paper. A deep thanks also to Yesenia Leon Niebla, Alfonso Espinoza, Luis Enrique Vazquez, and Jorge Baturoni Celaya for their collaborative research and composting toilet project management in Nogales. We both extend personal thanks to the colonia and barrio residents who showed us such hospitality and willingness to collaborate in our research. Thanks also to the Bureau of Applied Research in Anthropology and its community partners in Nogales. Thanks to our funders, the Inter American Foundation, Confluencecenter for Creative Inquiry, and the Latin American Studies Department at the University of Arizona for coordinating Tinker and Small Academic Collaboration of the Americas funding. We also thank the organizers of the Special Section and the reviewers for their helpful comments on an earlier draft. This is the third article in James R. Veteto and Joshua Lockyer (eds.) 2015. "Towards a political ecology of applied anthropology", Special Section of the Journal of Political Ecology 22: 357-465.
} 
déclaration de la résilience humaine dans le visage de l'inégalité sociale, la rareté des ressources, et de délabrement matériel. Dans la ville frontalière de Nogales, Kelly-Richards reflète sur les résultats de la recherche participative à la base communautaire, fait avec des étudiants techniques et les résidents d'une colonia informelle réglée. Une toilette à compostage a été construit, et la prestation de services du gouvernement municipal a également été étudiée. Nous invitons les lecteurs à considerer ces alternatives d'infrastructure comme un moyen d'explorer comment l'anthropologie appliquée peut avancer le potentiel émancipatiste de l'écologie politique urbaine. Ce sera grâce à une enquête collaborative de l'urbanisation inégale et le fourniture des services de base. Nous insistons sur les relations quotidiennes situé avec des infrastructures, dans les quartiers organisés d'un manière informelle. Praxis a été utilisé pour enquêter collectivement les relations complexes et enchevêtrées entre les grands projets d'assainissement, et des alternatives développées localement dans les zones mal desservies. Les deux études de cas révèlent les leçons apprises, et illuminent des ouvertures pour la justice sociale et de la durabilité environnementale.

Mots clés: Anthropologie appliquée, l'infrastructure, l'écologie politique, la praxis, gouvernance de l'eau, de la justice sociale

\section{Resumen}

Este articulo contribuye a estudios sobre el agua desde la perspectiva de la ecología política urbana a través de métodos de antropología aplicada y de praxis. Basado en dos casos de estudio realizados en zonas urbanas de Sonora, México, contribuimos a estudios críticos sobre infraestructura al enfocarnos en infraestructura grande y alternativas descentralizadas a la provisión de agua y servicios sanitarios. Asimismo, reflexionamos cómo utilizando métodos etnográficos es posible facilitar interacciones con pobladores de laderas marginales de dos ciudades desérticas con un rápido crecimiento urbano. En Hermosillo, ciudad capital del estado, Radonic destaca cómo la reflexión colaborativa con residentes de un barrio popular la llevaron a reformular su enfoque analítico respecto a la gobernanza del agua al reconocer infraestructuras informales como una manifestación de resiliencia frente a la inequidad social, escases de recursos, y deterioro material. En la ciudad fronteriza de Nogales, Kelly-Richards reflexiona sobre los resultados de una investigación participativa comunitaria centrada en la construcción de una letrina compostera con estudiantes y residentes de una colonia informal, mientras investigaba el suministro de servicios municipales. Nuestro articulo invita a conceptualizar estas alternativas infraestructurales como avenidas para explorar de que manera la antropología aplicada puede avanzar el potencial emancipador de la ecología política urbana a través de investigaciones colaborativas sobre urbanización desigual y suministro de servicios básicos. Resaltamos interacciones situadas y cotidianas con infraestructura en vecindarios que están organizados de manera informal. Utilizando praxis para investigar de manera colaborativa las complejas y entretejidas relaciones entre proyectos grandes de agua potable y saneamiento y alternativas desarrolladas a nivel local en áreas con déficit de servicio, estos dos casos de estudio revelan lecciones aprendidas e iluminan espacios para investigaciones orientadas a la justicia social y sustentabilidad ambiental.

Key words: Antropología aplicada, infraestructura, ecología política, praxis, gobernanza del agua, justicia social

\section{Praxis in urban political ecology}

Political ecology is an intellectual tradition that seeks to dismantle dominant accounts of environmental issues, considering these portrayals as often conducive to unjust socio-environmental change. Simultaneously, it also documents and nurtures alternative ways of thinking and acting to challenge mismanagement or to bring about change. This duality gives political ecology its concurrent potential as a hatchet and a seed, as Robbins (2012) describes it expressively. This characterization implies a shared normative stance in our own research: the understanding that current trends in resource access, control, and transformations have disproportionally affected certain groups negatively. The intellectual hatchet and the practical seed are illustrative of a political and ethical commitment towards sound environmental management and social justice. From this perspective, as Loftus (2012) and Perrault (2014) have argued, political ecology can be best perceived as praxis - the cyclical repetition of reflection and action aimed at transforming the status quo (Freire 1972). Engaging in a process of praxis that is collectively transformative, with wide reaching effects, is an ongoing focus and a methodological challenge for political ecologists. 
For applied anthropologists, praxis is the bedrock of the field. Applied anthropology, broadly conceived, refers to the generation of new social and cultural theory generated from problem-oriented research in a way that is consistent with community-directed needs. While in the $20^{\text {th }}$ century the relationship between theorizing and practicing was a recurring topic of intellectual debate in American anthropology, applied academic anthropologists have relied on praxis to rectify misperceptions that have characterized their field as atheoretical (See Hill 2000; Partridge 1987; Rylko-Bauer et al. 2006). As a post-positivist philosophy of knowledge, praxis does not see theory as prior to practice, but understands theory and practice as distinctive moments in knowledge production that are negotiated through action (Baba 2000; Eddy and Partridge 1987).

Applied anthropology's philosophy of knowledge in action aligns with political ecology's commitment towards a post-positivist methodology, as described by Perreault (2014). Recognizing that there are vital aspects of socio-natural relations that cannot be comprehended from a distance, he points to the centrality of ethnographic methods-like participant observation and semi-structured interviews-to political ecology. But for applied anthropologists, praxis goes beyond the researchers' ethnographic engagement in social reality and calls for involvement of research participants in the research process (see Saxton 2015). Based on her involvement in research partnerships along the U.S.-Mexico border, Austin (2004) argues that collaborative community research provides a solid foundation for actively addressing environmental problems through reflective practice and reciprocal learning. Austin asks researchers to acknowledge that the complexity and scope of socio-environmental problems render all of us ignorant-knowledge is, after all, always partial. In recognition of this, she argues for collaborative community research, which positions community members and researchers as co-learners, as a plausible pathway to expand our limited knowledge and to confront taken-for-granted explanations of cause and effect. Ongoing collective learning, which bridges how the problem and solution are conceived, presents a viable way to confront entrenched environmental problems for which there are no straightforward solutions (Austin 2010; Conklin 2006).

We argue that applied anthropology's conceptual and methodological commitment towards praxis can contribute to political ecology's potential as a critical hatchet and a practically engaged seed. We do recognize, however, that this commitment towards a normative agenda of social and environmental justice is not necessarily shared across applied anthropology, as critiques of the field's historical association with technicist and colonialist development models have pointed out (Escobar 1997; Rylko-Bauer et al. 2006; Van Willigen 2002). Political ecology's attention to power relations and its explicit focus on the politics of environmental issues can orient applied anthropology toward the reconceptualization of entangled social and environmental problems. Through the researcher facilitating collective praxis, where research participants contribute to the conceptualization and practice of research (as appropriate to the research objectives and ethics of the project), entrenched environmental problems can be examined and discussed from diverse perspectives. This process can potentially facilitate Loftus' (2013) suggestion that nature must be inserted into Gramsci's concept of praxis so that new worldviews, and thus ideologies of nature, can emerge from existing practices and everyday interactions. Explicitly focusing on challenging the dominant narratives of socio-environmental issues can reframe recurring problems according to local understandings and emergent responses.

This article contributes to the two traditions of applied anthropology and urban political ecology of water through a discussion of two case studies located in Sonora, Mexico. In the capital city of Hermosillo, Radonic reflects on how collaborative reflection with barrio residents led her to expand her analytical approach to water governance by re-conceptualizing informal water infrastructure as a powerful statement of human resilience in the face of resource scarcity and material disrepair. In the border city of Nogales, KellyRichards reflects on the outcomes of conducting community-based participatory research with technical students and residents of an informally settled colonia around the construction of a composting toilet, while also investigating municipal government service provision efforts. We describe how praxis, particularly the form and content of reflection, manifested in both of our research approaches. Haraway's (1988) idea of situated knowledges, that begin with the place and positionality of subjects in relation to their environments, supports our applied anthropology investigation of human-infrastructure relationships. Together, these case 
studies provide methodological insight leading toward collaborative, transformational research in urban political ecology.

Exploring these issues through communities' relationships with infrastructure reveals the relevance of off-the-grid forms of infrastructure for urban water governance. Ethnographic attention and engagement with material and discursive practices at the margins of so called "formal" infrastructure can respond to gaps in state provisioning. It is constructive of alternative realities. In short, these alternatives should not be romanticized, nor written off as ad hoc or inefficient - their histories merit empirical investigation. By jointly exploring with residents the intricate relationships between large piped water and sanitation projects and locally developed alternatives in under-serviced areas, our two case studies illuminate grounded research openings for social justice and environmental sustainability.

\section{Towards an everyday political ecology of infrastructural praxis}

In human-environment studies, urban political ecology is an increasingly popular framework for understanding the power asymmetries embedded in complex human-environment relations in cities, and hence for understanding the histories of their urbanization. At its heart is the conceptualization of the city as a process of continuous, and contested, socio-ecological transformations that can be approached by studying the dialectical interactions between humans and the non-human world that surrounds them (Kaika 2005). ${ }^{2}$ By extension, the city is understood as an active socio-environmental network, which produces and is produced by unequal political and economic relationships (Heynen et al. 2006).

In order to examine the material flows that unevenly shape the urbanization process in the context of capitalist power relations, studies in urban political ecology have predominantly focused on objects. Mostly, these have been large infrastructure networks, particularly water infrastructure (Gandy 2004; Heynen et al. 2006; Kaika 2005; Loftus 2012; Swyngedouw 1997, 2004, 2006). This scholarship provides important insights into our conceptualization of the urbanization process as well as the institutional arrangements, administrative practices, legitimizing discourses, and multiscalar politics of urban water governance. Politics include privatization, hydraulic engineering, water technologies, and social struggles. Analysis has tended to privilege the state and capital as sites of governance with a comparative neglect of the role of civil society, especially everyday forms of water management where the state is perceived to be absent. Some studies have demonstrated that informal and illegal water provisioning in underserviced areas are mobilized by state authorities to discipline marginal spaces and their populations (Meehan 2013), while others have shown that provisioning is among the processes of inclusion and exclusion in so-called informal spaces that create the tenuous effect of a coherent, organized state (Kelly-Richards and Banister 2015). Critically, though, there is a tendency in broader literature to describe the uneven waterscapes of urban areas as if the whole system and its related transformations are legible and able to be represented from a privileged standpoint. Attention to the agency of social movements or the everyday regulatory frameworks for the management of water "from below", on the other hand, has mostly focused on studies of water governance in rural locales (Boelens, et al. 2012; de Vos, et al. 2006; Lansing 2007; Perreault 2005, 2008). In contrast, we emphasize a different set of dynamics within this literature by examining the agency and everyday relationships between urban residents and water infrastructures. We consider the relationships between large infrastructural systems and often decentralized, locally developed alternatives, as well as the influence of land tenure politics, election cycles, and subjectivities formed in relationship to service provision.

The design and construction of infrastructure simultaneously establishes a series of bridges and barriers in as much as infrastructure reflects and reproduces systems of social exclusion and inclusion. Urban society shapes and is shaped by water, both materially and discursively, and water embeds and expresses social relations (Gandy 2004; Kaika 2005; Loftus 2006; Loftus and MacDonald 2001; Swyngedouw 2004). Thus, analyses of urban infrastructure point to the entrenched regimes of inequality that are reproduced in urban areas, creating differential citizenship for city dwellers. Being "off the grid" is more than a simple

\footnotetext{
${ }^{2}$ Understanding cities as socio-environmental assemblages, this approach integrates historical materialism's attention to the cities' inherent contestation with Actor Network Theory's recognition of the active role of non-human actors in coconstituting such assemblages.
} 
statement of infrastructural connectivity; it renders a description of how a particular population is produced as abject to the modern city (Anand 2012). The exclusion of sectors of the population from potable water or sanitation services provides clear examples of how differential citizenship is experienced (Anand 2012; Castro 2004, 2007). Furthermore, as Swyngedouw (2005) argues, the neoliberalization of water governance has in many cases limited the ability of the urban poor to participate in the management of the water resources they need on a daily basis. By studying infrastructure, we can also identify important sites for community-level social reproduction through local innovation, collective action, and developing alternative technologies.

Infrastructure is embedded into the most intimate and domestic of spaces, consequently shaping daily experiences in the city. As Dourish and Bell (2007: 417) argue, the experiential reading of infrastructure, then, sees infrastructure and everyday life as coextensive. In a similar vein, Loftus (2006) reveals how infrastructure features like the water meter regulate everyday life in the household, commanding the volume of water to be received and the time it will become available. Yet most urban political ecology scholarship lacks ethnographic accounts of the ways in which the everyday experiences of subaltern peoples shape urban socio-environmental networks. ${ }^{3}$ As Loftus (2012) reminds us, everyday moments of sensuous interactionfor example, household reproduction practices - are also involved in the production of urban environments.

Thus, everyday practices in the urban peripheries deserve careful ethnographic attention. These are sites in which established forms of control and privilege are more often challenged through what Holston (2007; 2009) labels insurgent citizenships. Reflecting on the unprecedented expansion of impoverished urban peripheries in Brazil where people live in conditions of illegal or irregular residence, Holston examines how new formulations of citizenship rights have emerged from everyday city-making practices and discourses by the urban poor. Insurgent citizenship refers to the everyday practices and demands for inclusion in the legal city - its property, infrastructure, or services - which come to constitute a struggle over the meaning and parameters of citizenship. For example, extending "informal" new pipes and mending them with rubber tape are practices that assert basic resource rights and work around the material inequality of a formal hydraulic system that excludes them. Put simply, we still have much to learn from the solutions and struggles that emerge in these marginal urban spaces.

Upon masterfully tracing the historical urbanization of Guayaquil to demonstrate how water is representative of power relations and empirically coupling political and ecological transformations, Swyngedouw (2004) points out that the absence of water and the exclusionary practices through which the urban water supply system is organized tells a story of urban deprivation and disempowerment. Our research findings suggest, however, that the reality on the margins is not so straightforward. On the urban margins of cities in Sonora, we found that these flows and metabolic processes look quite different. ${ }^{4}$ In these steep eroded hillsides covered with networks of PVC "illegal" pipes, or where residents wait to hail down the next water truck, the blurred boundaries between humans and technology is more pronounced. Bodies form part of the urban water infrastructure fabric - carrying containers of water, lifting hoses to fill rooftop cisterns, and disposing of cartons of fecal matter in the trash, among other tasks. Employing applied anthropology methods to study the daily lives and infrastructural processes in these marginal colonias presents a more nuanced view of urbanization, of how urban environments are shaped, politicized and contested. In turn, this analysis reframes mainstream understanding of government solutions involving large infrastructural system connection.

In our field sites, there is not merely disempowerment and deprivation, though they can often be dominant processes in such spaces. Ingenuity, hope, resilience, and other flows of power that do not follow the pipes are also important variables. By attempting to appreciate local visions of these issues, as well as local relationships with technology and nature, more "sustainable" alternatives to the governance of resources can be identified. Hybrid municipal and artisan networks may prove more capable of meeting growing urbanization and climatic change if official views of these artisan networks—or residents living in informally

\footnotetext{
${ }^{3}$ Notable exceptions include Anand 2011, 2012; Meehan 2013; Peloso and Morinville 2014.

${ }^{4}$ In a related line of inquiry, Banister (2014) provides a compelling interjection to urban metabolism and hydro-social scholarship through arguing for a Deleuzian influenced ontology of matter, flux, and flow.
} 
established neighborhoods-were not negatively viewed as illegal and thus undeserving of consideration. Conversely, local socio-environmental relationships and histories must be better understood before decentralized alternatives can be advocated for or implemented. Residents' relationships to technology would be quite different if misleading promises of piped connection made by candidates during election years did not gloss over the water pressure deficiencies, energy requirements, monetary challenges, and property relations preventing urban water and sanitation provision. By spending time observing and developing collaborative research relationships on these hillsides, we assess the incomplete aspects of these processes, processes that are frequently visible from the margins. In doing so we contribute to an underdeveloped dimension of studies on urban metabolism.

Informed by applied anthropology, our praxis began at the margins with research collaborators. We began with embodied spatial practices in these neighborhoods (Cahill 2007). Political ecology concerns of praxis expand this situated analysis to the surrounding socio-natural context. While praxis is human-centered, it is also a relational process of becoming with actors and place (Loftus 2015). Thus, by orienting our research toward water infrastructural processes at different scales, collaboration, critical reflection and action took on distinct forms.

Praxis-a repetitive power-producing activity, like pedaling a bicycle- drove this process. As Cahill (2007) describes, collective research praxis is iterative and slowly negotiated. ${ }^{5}$ Our methods were designed to collectively explore the socio-ecological and socio-technical relationships involved in water and sanitation problems. Contrary to the critical pedagogy approach of Freire (1972) that conceives of transformation as a singular event, Cahill (2007) argues that subjective transformation is an ongoing negotiated process. Her narration of this process is instructive for embodying praxis in writing. Similarly, instead of aiming for one transformative moment, our efforts to collaborate with residents was a long distance pedaling commitment toward understanding water infrastructure from the situated perspectives of residents, in turn producing new knowledge through this practice. While political ecology recognizes the political potential of praxis, methodological conversations that discuss how to engage in processes of praxis are limited. To address this gap, our methodological approach is to understand governance from multiple angles, and to have the research process itself contribute to addressing these ingrained problems. Within the field of urban political ecology, our approaches indicate starting points for deeper, collaborative research.

Below, we provide background on key changes to water and sanitation governance in Mexico since the 1970s. We then transition to detail the methodological and empirical findings of our two case studies in Hermosillo and Nogales. We proceed to discuss the findings generated by bringing our complementary approaches and case studies into conversation. In conclusion, we summarize the relevance of our findings for infrastructure decision-making, political ecology praxis, and applied anthropological pursuits.

\section{Water and sanitation governance in the Mexican and Sonoran context}

Faced by a rapid and disorderly increase in urban population, in 1976 the Mexican federal government created the Secretariat for Human Settlements and Public Works. The responsibilities over urban water and sanitation services were then transferred from the Secretariat of Hydraulic Resources to a new urban-focused federal agency. In 1982 this agency was then absorbed by the newly established Secretariat for Urban Development and Ecology (Pablos and Pineda 1999). Attuned with the global trend towards decentralization and the transfer of water and sanitation services to lower tiers of government, the construction and administration of such services were technically transferred to the states and counties in 1983. As PinedaPablos (2002) explains, the first step towards decentralization was the transfer of responsibilities to the states, who then assessed whether or not to transfer the services to counties, a process that took over two decades. Decentralization was a widespread strategy for the federal Mexican government but it only resulted in the partial decentralization of resource governance, with some key responsibilities remaining centralized (Rodríguez 1997).

\footnotetext{
${ }^{5}$ Cahill's (2007) feminist post-structural orientation toward praxis, enacted through Participatory Action Research, is distinct from our research approaches. Irrespective of this difference, we find her writing on participatory praxis is relevant and informative.
} 
As part of its move towards decentralization, the federal government created the National Water Commission in 1989. This decentralized organism became the regulatory agency for the urban water systems operated by the state and municipal administrations. Pointing to the existing deficiencies in water management, the Water Commission proposed the creation of decentralized and autonomous agencies at the municipal level and encouraged participation of the private sector in the management of urban water services. Decentralization thereby entailed the creation of paramunicipal companies, which became responsible for the administration of drinking water and sewer systems in urban areas. Known as organismos operadores municipales, these agencies had legal personality and their own assets.

To encourage the participation of the private sector in municipal water and sanitation, in 1992 Mexico issued the National Water Law (Pineda-Pablos 1999; Wilder and Romero Lankao 2006). Article 27 of the 1917 Mexican constitution originally defined water as a public good held in trust by the federal government (Whiteford and Melville 2002), but with the passing of the National Water Law, Article 27 was reinterpreted. Water provisioning services and infrastructure became the object of commercialization, although federal water authorities assured citizens that commercialization did not entail the privatization of Mexico's water (La Jornada 1992: 37, in Castro 2007). In keeping with national neoliberal reforms, this shift was underwritten by an official discourse that blamed the water crisis on "the ingrained dependency culture within which the government has played a paternalistic role of supplier, donor, benefactor" (CAN 1990: 16, in Castro 2004). The new water law was directed at fostering a new water culture of responsible consumers. Accordingly, the state established market mechanisms for the circulation of water rights and water became "a resource which has an economic value and society must pay for it" (CNA 1993:11 in Castro 2004). This shift implied changes in the relationship between water and the state, water users, and private investors. ${ }^{6}$ The shift of costs to water users, municipalities (passed on to customers via full cost pricing), and private companies, arguably served to further marginalize populations without access to basic services, notwithstanding its intentions of citizen participation (Barkin and Klooster 2006). Despite these legal modifications, the participation of the private sector remains marginal. From 1992 to 2010, there have been 33 contracts, 70 percent of which are "build own operate \& transfer" contracts (Agua 2010).

In Sonora, the municipalities of Hermosillo and Nogales were the last ones to assume the responsibilities over water and sanitation services in 2003 and 2004, respectively. Given the deteriorated conditions of the urban infrastructure and the challenges of rapidly expanding urbanization, in 1996 both municipalities had signed agreements with the state administration for the state-level Water Commission for Drinking Water and Sewage to maintain control over the municipalities' respective services. In terms of basic infrastructure coverage, the wave of urban modernization in Sonora is neatly summarized by two often quoted and gratifying figures: 94 percent of households have potable water coverage and 77 percent hold connectivity to sanitation services. Census data from 2010 states that in the municipality of Hermosillo 95 percent of households are connected to the water grid and 94 percent are connected to sanitation services, while in the municipality of Nogales 95 percent of households are connected to sanitation services while 77 percent have potable water (INEGI 2010). ${ }^{7}$ The figures for water coverage are not limited to indoor plumbing: they include any houses with a water connection within their lot, and do not account for the conditions of the existing infrastructure. Our on-the-ground observations indicate that houses counted as connected are in reality underserviced due to decrepit leaky pipes and low water pressure. Similarly, figures for sanitation services include households connected to the public sewage system as well as households with septic tanks and pipes discharging to gullies or arroyos, instead of connected to a treatment facility. Numbers broken down by the type of sanitation service at the municipal level are not available. Furthermore, for the case of Nogales, scholars argue and empirical data from this study suggest that these figures must be significantly lower (Wilder et al. 2011). Considering the population of Nogales is estimated to be around

\footnotetext{
${ }^{6}$ Across the country, these changes became institutionalized as Mexican states approved legislation authorizing private participation through contracts and concessions for construction and administration of water infrastructure and service management.

${ }^{7}$ The figures for water coverage are calculated based on household—not population numbers—following Mexican national statistics protocol (INEGI 2010). The figures were calculated by dividing the total number of households in each city by the amount of households identified with available connection to the water grid.
} 
350,000 (Austin 2010), much higher than the official INEGI (Instituto Nacional de Estadistica y Geografia) calculation of 220,292 Nogales residents in 2010, it follows that many of those unaccounted by the census lack piped service connection.

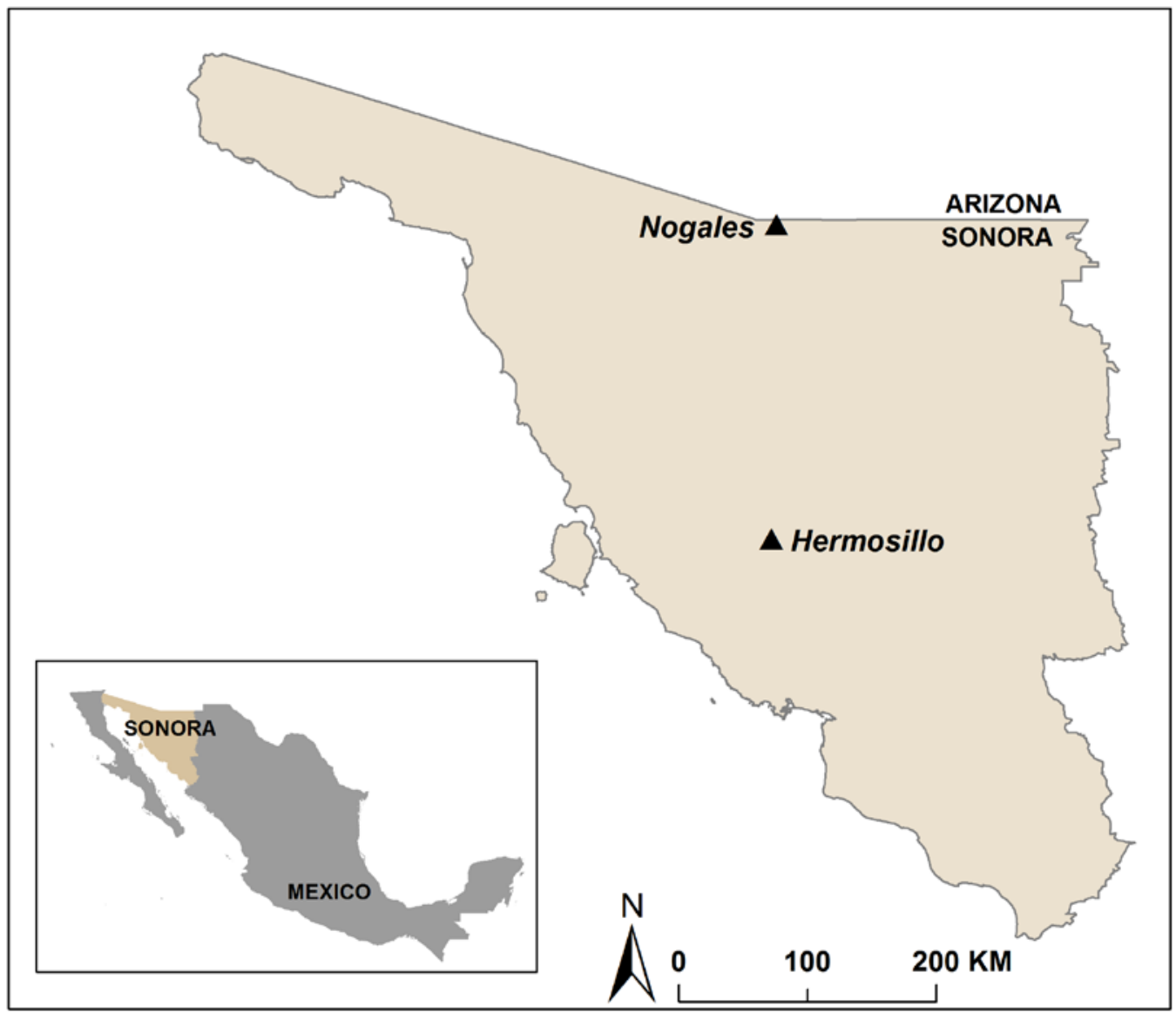

Figure 1. The study area: The cities of Nogales and Hermosillo in Sonora, Mexico. Map made by Lily House-Peters.

\section{Hermosillo}

From the 1950s onward, water distribution and sanitation networks in Hermosillo grew in a chaotic way following the increase in demand for service provisioning by the rapidly expanding population. The construction of the Abelardo L. Rodríguez dam and associated irrigated canals in the mid-1940s was a catalyst for economic and social transformation of the capital city. Infrastructure construction initiated an era of relentless urban expansion. As agricultural activity in the coastal valley expanded, Hermosillo's population more than doubled, rising from 43,516 in 1950 to 95,978 in 1960. As the industrial and manufacturing sector grew in the ensuing decades, population growth continued at an accelerated rate, reaching 792,000 in 2010 (INEGI 2010). During this period, Hermosillo progressively shifted its supply source of water from the Abelardo L. Rodríguez reservoir to groundwater wells in the periphery of the city (Scott and Pineda 2011).

In 1998, the Abelardo L. Rodríguez reservoir and a number of wells dried up. State authorities responded by implementing water rationing or tandeo to guarantee water availability for the summer season, when temperatures easily reach $120^{\circ} \mathrm{F}$. The city was divided into 115 hydrometric sectors, which took turns to receive their 8-hours of daily water allotment. Households that could afford it installed 1100 liter water 
tanks on their roofs to guarantee in-house water access throughout the day. Those who could not afford water tanks came to rely on assorted containers for storage. Over the next decade, the production of existing wells decreased dramatically, forcing the city to expand its hydraulic frontier and make the tandeos a yearly occurrence in dry summer months. Yet, over this period per capita water intake across the city remained at 300-345 liters per day, among the highest in Mexico (Pineda 2006; Salazar Adams 2010; Wilder et al. 2010).

In 2011 Hermosillo was declared to be in a state of emergency due to water shortages. As the tandeo's dry-period was extended, state authorities proposed inter-basin water transfers through a new aqueduct as the solution to the crisis. The aqueduct would eventually bring water from the Yaqui River basin to the Abelardo L. Rodriguez reservoir just outside Hermosillo. Press releases and government reports issued by state authorities ascribed water shortages principally to a decline in already-limited freshwater supplies. Researchers, however, point out that urban water shortages are the combined result of inconsistent water pressure, unkept old pipes, and irregular connections, which together produce significant leakages. For example, Salazar and Pineda (2010) report that in 2006 the city produced just over 85 million cubic meters of water but the municipal water agency only invoiced 53 million cubic meters. This implies that 38 percent of the water was lost through leakage and/or clandestine connections.

It is well understood that while economic and political agendas often influence official definitions of water scarcity, on-the-ground experiences of scarcity are shaped by household location, access to technological fixes based on income level, and daily water management practices and expectations of supply (Johnston 2003; Mehta 2003). I (Radonic) began ethnographic fieldwork in Hermosillo in 2011, seeking to document the strategies mobilized by residents in low-income neighborhoods to expand and secure access to water services as well as to assess their position towards the proposed aqueduct. I selected two neighborhoods located on the hills at the center of town that are historically associated with Yaqui (yoeme) indigenous settlers, many of whose descendants continue to live there and identify as Yaqui. These neighborhoods are among the barrios viejos of Hermosillo, which predate the city's urban expansion. According to the maps of the municipal water agency and census information on water and sanitation services, households in these barrios are technically connected to the formal water network. However, in reality many households lack access to water service. For some households this is due to low water pressure and decrepit infrastructure, and for others it is due to lack of connection after an original lot was informally subdivided into multiple lots for independent households. Most homes do not have large rooftop water tanks but they all have various smaller containers upon which they rely on a daily basis irrespective of the tandeo. The situated knowledge of water infrastructure on the hillsides points out asymmetries between neat government accounts and the wicked urban worlds where people dwell.

Influenced by social movements theory and in light of organized resistance against the aqueduct in Yaqui territory (see Radonic 2015), the study sought to document neighborhood level mobilizations over access to water resources in the city. Before starting fieldwork I asked four community members who I knew occupied leadership roles within the urban Yaqui community to serve as informal advisors on the project. My original idea was for all of us to meet periodically and reflect on the latest developments on the construction of the aqueduct, related water-rights conflicts, and citizen mobilizations. Part focus group and part research meeting, these gatherings were meant to engage the five of us in reflective practice and reciprocal learning: preliminary data was to be examined and community assets enhanced through increasing access to information relevant to their water struggles. Two months into the project, scheduling conflicts and neighborhood bickering showed that my praxis would not follow the collaborative-based participatory research format I had outlined. Group-based reflections were replaced by one-on-one conversations with each collaborator. Enunciations of fijate -notice that!- in response to my informal presentations over coffee signaled an observation was worthy of attention and further exploration. These meetings were thus key in steering the project to consider important dimensions of water governance that were beyond the initial framework of analysis -namely, attention to the local work involved in expanding and maintaining the barrios' water network. Ethnographic attention was therefore directed towards the network of pipes along the alleyways, as much as to the aqueduct that was the original study focus.

My interest in exploring the dynamics of infrastructure maintenance was met with multiple fijates from my local advisors. They recommended people in the barrios to interview and government offices to 
visit in order to begin deciphering the history of the infrastructure and the maintenance work involved. They were particularly interested in hearing about the interviews with government officials. In the barrios I expanded my semi-structured and informal interviews to elicit participants' elaboration of the inconspicuous dimensions of the water infrastructure tracing the alleyways, which was portrayed simultaneously as a nuisance, not unlike a meddling neighbor, and as a locus of work. As I conducted interviews with barrio residents in their households and participated in the activities of daily life, I came to learn the alleyways of the barrios. Unmapped, unpaved, and often flooded, the alleyways are the only circulation routes for people and water. A network of pre-1960s galvanized pipes, thick rubber hoses, $1 / 2$ inch $(12.7 \mathrm{~mm})$ PVC pipes, and regular garden hoses retrace the main alleys. Because of the rocky substrate, water pipes are above ground, which makes them vulnerable to foot-wear, gravel-slides, water damage, and vandalism.

Water pipes frequently leak and can rapidly turn the alleys into arroyos. Residents and municipal engineers agree that water emerges from holes owing to corrosion (due to the pipes' old age) or from informal connections that have come loose. However, as much as there are holes, there are also repairs made with thick rubber bands, electric tape, and clamps (Figure 2). This speaks to the residents' constant maintenance of their improvised and decrepit system. These circumstances create a space where people must routinely engage with the management of their own water provisioning if they want to cook, shower, wash clothing and dishes, and maybe even run an evaporative cooler during the hot summer months (Figure 3). In the barrios the strategies mobilized to maintain access to water are in-situ actions directed at engaging with the municipal water agency—whether through explicit agreement or not—by reworking the old infrastructure network. In this "multi-authored maze" individual residents play an active role in building, altering, and maintaining the municipal water supply system. Water infrastructure along these arterial alleyways is a collective project of recurrent labor.

Archival work and interviews with neighborhood residents and government officials contextualized the history of these barrios' water infrastructure network within the state hydraulic development and the centuries-old conflictive relations between the Mexican government and the Yaqui tribe. Following technical explanations of the topographical challenges to expanding infrastructure to hillside barrios, municipal personnel often remarked on the neighborhoods' social dynamics and ethnic composition. They argued these traits further hindered work in the barrios. More extensive reflection sessions with local research advisers provided me with rich accounts on urban Yaqui history, leading my collaborators to consider how history influences their relationships to water infrastructure. More than the neighborhood's rough and un-mapped terrain, they recognized what was preventing municipal workers from delivering water bills and checking for leaks was the neighborhood's reputation as lawless territory. As one person put it: "They do not dare to come in; they are afraid we will throw stones at them. But that's a thing of the past, those gangsters are all grandpas now... or dead, or in jail" (Velez, 2013). ${ }^{8}$

Water scarcity has become the central organizing principle for municipal and state water governance in Hermosillo and many other cities. By equating water scarcity with the tandeo, state authorities conceal the kaleidoscopic nature of urban water access. This logical fallacy dismisses the role that obsolete water networks and lack of connectivity play in everyday experiences of water shortage independent from the tandeo and regardless of high investment in hydraulic projects like the aqueduct. Long-term practices of selfprovisioning and sustained experiences of scarcity position residents of neighborhoods at urban margins outside hegemonic discourses found in state-issued statements that equate water scarcity with tandeo and water security with investment in engineering water supply. The unruliness of the barrios' homemade infrastructure not only denounces the gap between state rhetoric of universal coverage and their infrastructural practices, but illustrates the need to study the governance of water infrastructure from multiple angles to understand water access and distribution as the integration of formal and informal systems (see Furlong 2014 and Meehan 2014). While for individual households these infrastructural adaptations are an act of self-reliance, at the barrio level they constitute a form of class struggle as indigenous urban residents claim a right to the city by expanding their access to water resources.

\footnotetext{
${ }^{8}$ All individuals interviewed were given pseudonyms to protect their anonymity.
} 

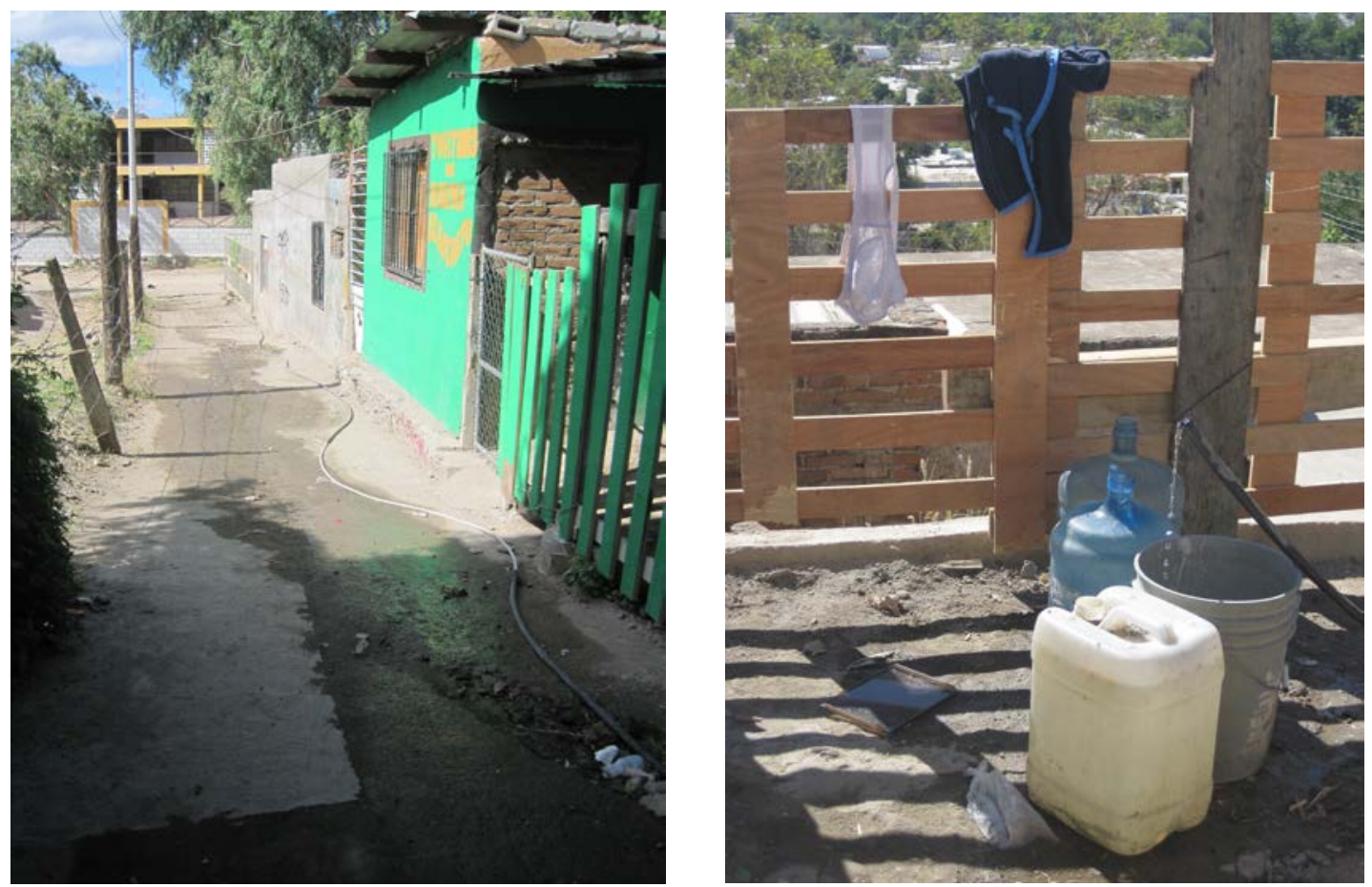

Figure 2. A hose running up the alleyway in a barrio Viejo of Hermosillo serves as informal water pipe. Source: Lucero Radonic.

Figure 3. Containers being filled for daily usage in barrios viejos, Hermosillo. Source: Lucero Radonic.

\section{Nogales}

In Nogales, too, there are multiple barriers to equitable water management. The piped water and sanitation system has been unable to keep pace with a rapidly growing population. Connection to water and sanitation is made more difficult and costly by historical land-invasions, which have led to informally organized neighborhoods and self-constructed homes, many on steep hillsides (Wilder et al. 2011). Following the promotion of maquiladora factories in the early to mid-1960s forward, Nogales's population grew from 39,812 people in 1960, to 68,076 in 1980, and 220,292 in 2010 (INEGI 1960; 1980; 2010). From the beginning, maquiladora-led growth raised housing and land prices, providing workers with little option but to construct their own homes "informally" due to shortage of affordable housing and land (Camberos and Barojas 1988). Similar to Hermosillo, Nogales's water is managed through a tandeo system (39\% of the population are reported to have access 24 hours a day), with low pressure and topographical challenges hampering system operation and expansion following its initial design in the 1940s (Ingram and Laney 1995; Varady and Morehouse 2004; Wilder et al. 2011). The city receives its potable water supply from three diminishing groundwater sources, which are projected to be further taxed by population growth, increased grid connections, and hydrological variability (Prichard et al. 2014). Water sources include the Los Alisos aquifer located to the south of the city (pumped over elevation divide), the Santa Cruz aquifer to the east, and the Nogales Wash aquifer within the city (Morehouse et al. 2000; Prichard et al. 2010, 2014). There have also historically been issues with water contamination in the Santa Cruz and Nogales Wash aquifers (ibid).

Domestic water use is accessed via two sources, piped connection provided by OOMAPAS (Organismo Operador Municipal del Agua Potable Alcantarillado y Saneamiento), the municipal water and sanitation agency, or trucked water provided by private and municipally operated pipas, water tanker trucks 
(Figure 4). While piped service connection is desired, water access can be insecure for those with and without piped connections (Wilder and Slack 2010), depending on their topographical location and relationships with the pipa drivers. As was the case in Hermosillo, in Nogales piped water is not necessarily more secure than trucked-in water, particularly in areas where pressure is weak during the hotter months of the year (Wilder and Slack 2010). However, hailing down pipa trucks and overseeing water provision requires additional labor from residents of more recently settled popular colonias (typically areas of lower socio-economic status), furthermore, water from private pipa trucks is typically more costly. Piped water is also costly, reflecting the relative scarcity of the resource, and the engineering and electricity costs of the system. Those who cannot afford to pay monthly bills are additionally insecure. Put simply, there is no clear, equitable solution for water and sanitation provision. In the densely populated eroded hills and arroyos, insecurity is unevenly distributed along interconnected socioeconomic divisions and topographical variation.

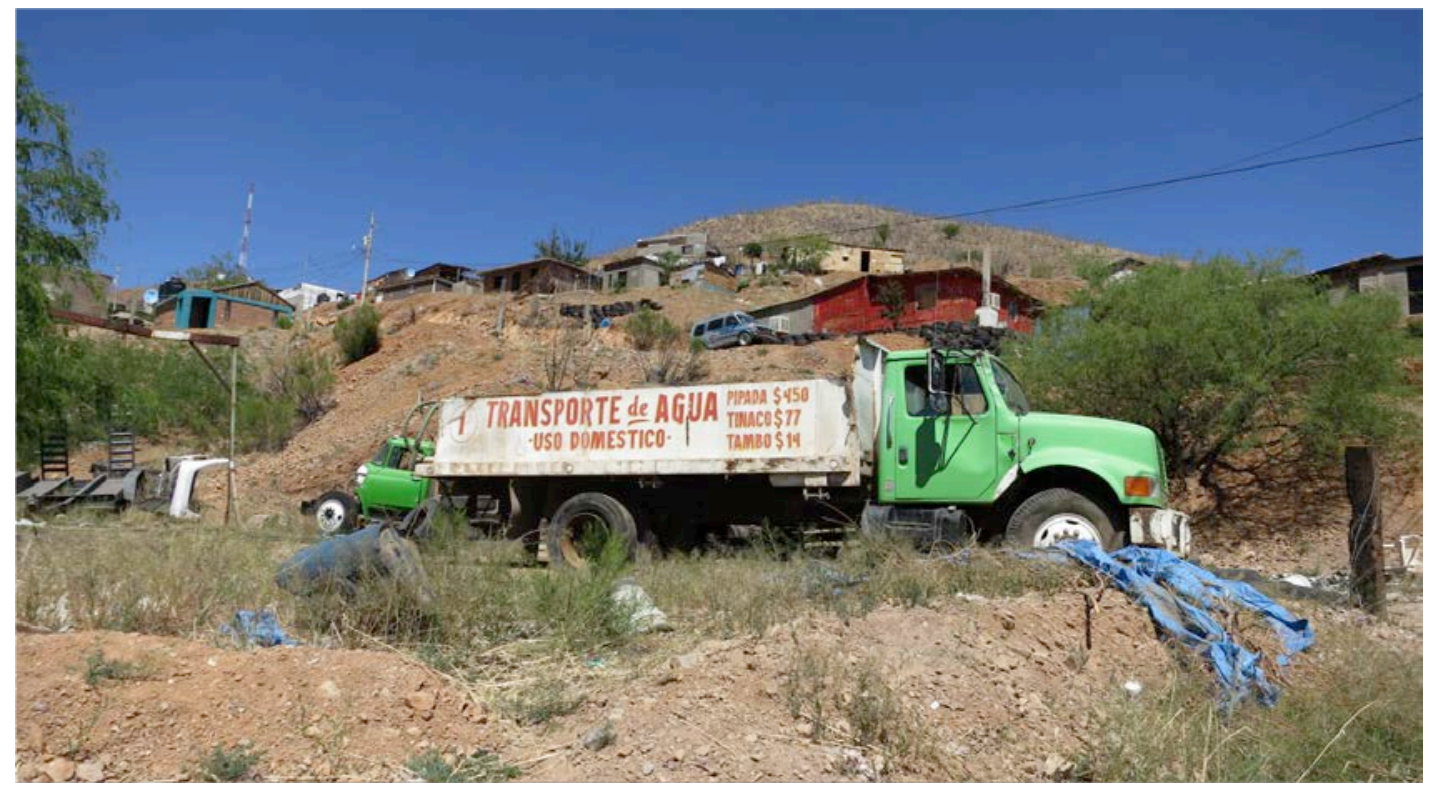

Figure 4. Pipa, or water truck, in a low-income colonia in Nogales. Source: Sarah KellyRichards.

As in Hermosillo, in Nogales piped sanitation and water access to the grid is primarily limited to older colonias. Those without piped sanitation must develop their own disposal systems. This ranges from using cardboard containers and disposing of them in the garbage, to flushing toilets into pit latrines (large, handdug holes). Residents must then pay to have the pits emptied. These solutions rely on the funding and technical knowledge of residents. The effects of a neighbor's sewage disposal method are often borne by others downstream, typically those further down the steep hillsides and within the snaking arroyos, particularly during floods triggered by summer rain.

Building from long-term collaborative relationships in Nogales around environmental alternatives, I (Kelly-Richards) partnered with four students, Yesenia, Alfonso, Enrique, and Jorge, at the Instituto Tecnológico de Nogales (Technical Institute of Nogales, ITN). In collaboration with a grassroots community organizer, we introduced a locally developed composting technology to a colonia largely without piped water or sanitation. The students and I oversaw different portions of the project. With help from Nogales community partners who were experts in this local technology, the students led the composting toilet project management. Our intention was that they gain this leadership experience for future employment 
opportunities in the maquiladoras, particularly since the manufacturing model does not often provide leadership training to local residents.

Over the course of a year, we presented and discussed composting toilet technology with residents, built a demonstration composting toilet at the community center, began toilet maintenance education, and started monitoring toilet use. Decisions about the composting toilet location, and related workshops, were made with colonia residents. During the same time frame, a municipal government project to connect portions of the colonia to piped water and sanitation progressed and faltered. This left the colonia divided: a freshly paved street with expectant pipes installed underneath contrasted the surrounding eroded rock and dirt roads, many of which meander and quickly divide into many short dead-ends.

I decided to compare and contrast the infrastructure dynamics and perceptions of the governmentsponsored project with the community-based composting toilet project as parallels emerged. During interviews with residents, access to potable water was identified as more pressing than sanitation services. Following their tales of long waiting periods for the pipa water trucks and the high cost of potable water in comparison to their low maquiladora wages, nearly every resident shared the same phrase, "Batallamos para el agua," we struggle for water. In total, forty-four interviews were conducted with residents, municipal government officials, knowledgeable community organizers, and long-term residents of Nogales.

Constructing a composting toilet on the premises of a community center demonstrated the importance of social relations for supporting and developing alternative infrastructure technologies, as well as residents' expectations following ongoing election promises and service connection projects. Our engagement became a shared learning experience, and informed my investigation of the politics of service provision. Infrastructure workshops on alternative building technologies and the composting toilet offered spaces for residents to discuss their expectations of government-sponsored infrastructure. I observed and listened to residents describe their sense that services were progressing, which they equated to becoming fully connected to the city. This understanding of development led some to expect connection to government services, and to see less utility in alternatives.

Before research commenced in the colonia, OOMAPAS employees placed pipes under the main road leading to the community center. While these pipes were not yet connected to the existing grid, their presence and the promises made in relation to them altered residents' actions and perceptions. Government employees' interactions with the colonia, especially reaching out to small groups and asking residents to self-organize, raised expectations among some residents while disenfranchising others. Depending on which part of the colonia officials visited, residents were offered different arrangements and prices for connection. These disparate promises followed topographic variation in the colonia, with the highest costs for connection offered to those living in deep gullies far away from existing infrastructure.

The government project was linked to binational plans for the Los Alisos wastewater treatment plant south of Nogales, Sonora, and partially funded by the federal Hábitat program. Federal funds are granted to areas of lower economic status designated through survey data by the Hábitat program, which is operated by the Secretaría de Desarollo Social (SEDESOL, Social Development Secretariat) (Hernández, 2012). The funding approaches of the binational agreement and the Mexican federal government had different scalesneighborhood connection versus smaller, designated polygons, which marked areas of lower socioeconomic status. This ultimately led to a fragmentation of the connection plan: the pipes remain unconnected where they were installed, and at the end of research, many months after grid connections were supposed to be finished, much of the neighborhood still had no piped sanitation or water infrastructure.

Following these government promises and construction, more than one resident expressed that the existence of the pipes and the previous installation of electricity were evidence that water services would soon arrive. One woman described their process of lobbying the government for electricity (López, 2012). When asked if she would do the same for water, she replied: "No, the water should arrive, there are pipes. There have been rumors that wastewater services are coming" (ibid). An older woman explained a different political view: "Who knows when they will connect them [homes to services]?" she asked. "The government promises many times and does not do what it says" (García, 2012). The mixture of high expectations and uncertainty is fueled by political promises during election periods. In interviews, residents mentioned 
promises made by each municipal President to regularize land titles and provide piped water and sanitation services, spread by party representatives in the colonias before elections. Amidst the tenuous establishment of state authority in planning efforts, I found that ambiguity is an emergent characteristic of these infrastructure interactions (Kelly-Richards and Banister 2015).

Praxis occurred on multiple levels throughout the research process. The students accompanied me on most interviews; we reflected on how the research process and composting toilet construction was proceeding each time we met. The workshops served as spaces for group reflection with colonia residents, although, due to uncertain schedules and communication, attendance fluctuated. Based on feedback from community leaders, we ended up organizing art projects with children at the community center, and teaching them about composting toilets, eco-building techniques, and sustainability. We also left manuals on how to build these locally designed composting toilets in the community center, and facilitated introductions through workshops to knowledgeable community partners. Following the final workshop, a few residents who participated in all of our gatherings communicated that they participated because of the hope they found in young people building relationships and projects in their colonia, not only because they were interested in composting toilets.

The community-based approach to research revealed the depth of social divisions unfolding along colonia lines. The ITN students I collaborated with described their own shifting understanding of the root causes of water and sanitation problems in Nogales - while "illegal" colonia residents are often publically blamed, they saw larger structural issues at work, specifically rapid urbanization and economic development. This rhetorical framing obscures how processes of sanitation and water provision are politically and economically intertwined with land title regularization (Kelly-Richards and Banister 2015). As the neighborhoods that lack services are primarily on the margins of the city away from the city center, it is possible for many Nogalenses to avoid observing the extent of the arduous living conditions that visits to the neighborhoods would make apparent. Thus, a process of social differentiation transpires at the city-level whereby many people in Nogales no longer witness the difficult conditions in newly settled informal colonias.
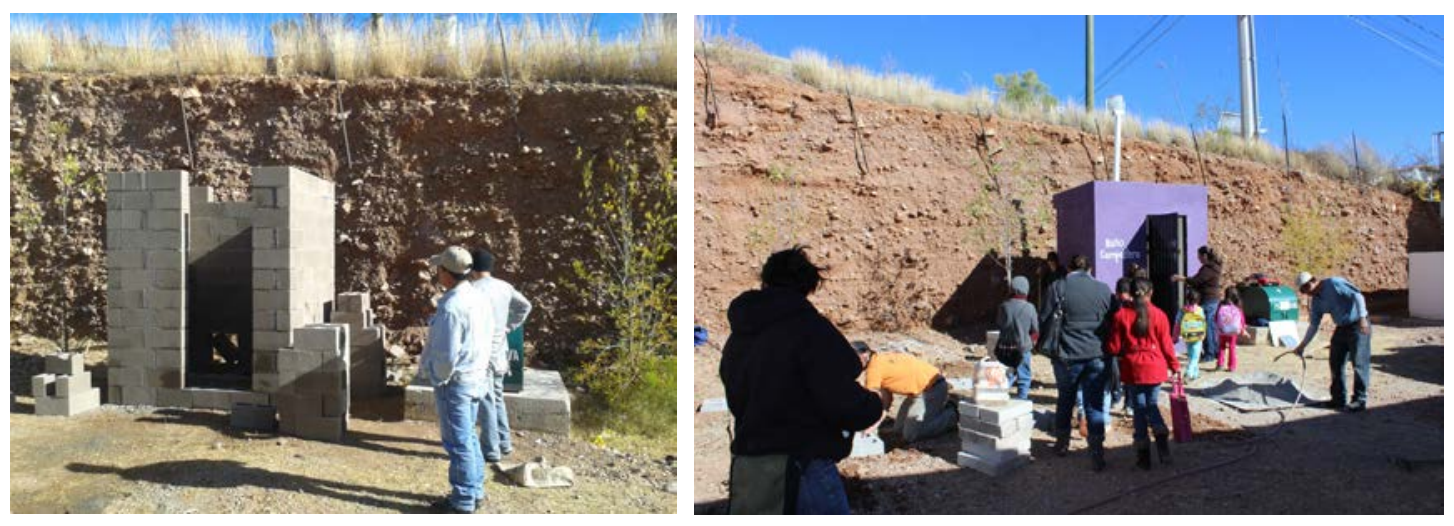

Figure 5. Construction stages of the composting toilet in Nogales. Source: Sarah KellyRichards.

Consequently, this research approach led me to conclude that there are topographical, economic, and social dimensions of colonia development that constitute barriers to developing alternatives. The threat of eviction by landowners and/or expropriation by government officials is ever-present. Organizing is also difficult. Unlike the barrios viejos of Hermosillo, this colonia is less than fifteen years old, populated by 
residents from all over Sonora and other parts of Mexico. ${ }^{9}$ It is difficult for people to find times to meet-and plan - with the unpredictable and long hours they work in maquiladoras and other jobs in related industries. There is significant turnover in neighborhoods, accelerated by border crossing and job insecurity. Safety and trust in colonias is violated by the infiltration of drug trafficking in these fledgling communities, which residents expressed disrupts social cohesion. While it can be easy to romanticize off-the-grid solutions, the political realities of the colonias make alternatives difficult.

In 2013, three of the students and I attended the Society for Applied Anthropology's annual conference in Denver, CO, to co-present our findings. We collaboratively wrote and presented our work in English and Spanish. Below is the conclusion that included each of our voices, but emphasized the students' perspectives:

At the beginning, we didn't realize the problems in the neighborhoods of Nogales. But after involving ourselves in this project we, as people from Nogales, learned to see the political situation of these informal communities that lack basic services such as water, sewage, and electricity. We realized that the lack of services is much more complicated, and it is related to laws, histories, economy, topography, water scarcity, and politics - but in our conversations, we could not agree on just one cause of the problem, nor one solution (Kelly-Richards et al. 2013).

We emphasized that these infrastructural engagements must be collectively discussed with local residents in order to begin addressing such complex provision problems.

What this process exposed is that the steep and eroded hillsides of Nogales, and the low water pressure of the existing grid, may well require a more pragmatic and hybrid approach to piped water and sanitation provision. Through this reflection, we saw that the moments of hope and optimism were when we brought people together to learn and exchange in workshops. The reflection of praxis with ITN students and community members was where the complexity of issues began to be grappled with more deeply. Research findings were thus not concrete solutions, but methodological suggestions of more equitable and inclusive paths forward.

\section{Discussion}

As the two case studies above show, we adopted different engaged research approaches to combine applied anthropology and urban political ecology. The scope and timeline of each project, its research objective, and the nature of the questions to be addressed required markedly different project designs. In Nogales, long-term partnerships between university researchers, community members, and the technical institute, facilitated a clearly defined hands-on component. This allowed for a more structured collaboration with the students. In the barrios of Hermosillo, where research relations were in their early stages, the fluid membership and informal leadership of neighborhood groups was conducive to one-on-one collaborations but not to structured institutional partnerships. Likewise in Nogales, the less-controversial nature of the interview questions allowed for student collaborators to attend the interviews, a valuable yet less explored research strategy. For example, they were able to provide insight on the party politics of interviewees and contextualize data gathered within Nogales's history. Contrary to this, the heated political climate of Hermosillo's water strategies and the strained neighborhood relations necessitated that interviews be confidential. Preliminary data needed to be carefully processed to ensure the removal of any identifiable information before oral summaries could be shared with research collaborators. Both projects were designed to include collaborative reflection as central to the research process. However, due to these differences, the relation between theory and practice via collaboration with research participants-the process of praxistook correspondingly different forms. Overall, we found the iterative process of reflection and action in research provides a mechanism to integrate political ecology's critical hatchet and hopeful seed.

\footnotetext{
${ }^{9}$ Due to the political sensitivity of the research topic and the vulnerability of residents to government power, the name of the colonia is not identified.
} 
The determining characteristic of praxis is its situatedness, thus we are reluctant to offer any standardized recommendations. Diversity in research situations allows for radically different research processes; the parameters for making praxis more systematic are context-specific. Other authors have already shown that there is not one model for creating research partnerships with community members, and that collaborative-based research may not be an appropriate approach for all projects (Austin 2004; Lassiter 2005). Following setbacks and altered trajectories, the modes of praxis were integral to our findings, but they could be strengthened in future research. In retrospect, we see ways to deepen and expand shared learning. And, we see the benefits of developing a systematic way to collect data and evaluate shared processes of reflection.

In light of this, we advocate maintaining attention to developing spaces for collaborative reflection in urban political ecology research projects. While pushing collaborative reflection forward, it is imperative to continuously question who is included, why, and what the power dynamics at play are in collaborative spaces. Incorporating these new collaborative components into research design is not easy - it takes time, coordination, individual moments of assessment, and ongoing methodological experimentation.

There is no doubt that the neighborhoods we worked in experience prolonged structural neglect, and those households' experiences with water shortage are dynamic processes. Discourses of water scarcity in Hermosillo and on illegality in Nogales are mobilized by municipal and state authorities to frame both water management plans and solutions - they are not necessarily cognizant or mal-intended, but nonetheless are informed by and reinforce ingrained social biases. We observed these discourses circulating in government documents, newspaper accounts of public events, and articulated in interviews. Effectively, these discourses work to normalize realities that residents of marginal neighborhoods have been living with for many years. These discourses neutralize residents' claims to highly functional water and sanitation services.

Informed by a political ecology perspective, our two case studies have challenged technical solutions for water governance in contemporary Sonora, which we argue are conducive to unjust socio-environmental relations in many growing urban centers. To say that the correct solution is either a large infrastructure system or to romanticize decentralized alternatives is to avoid the infrastructural realities and social practices which have developed around them. Critically, research collaborators' reflection added nuanced understanding of the infrastructural challenges and state-society relations emerging in these marginal colonias. These insights reframed our conceptualization of state-sponsored infrastructure and alternative infrastructural strategies for water and sanitation provision.

A related and fundamental issue with urban water governance is the positioning of low-income neighborhoods as abject to the modern city. As both cases illustrate, government employees-from technicians responsible for fixing leaky pipes to engineers charged with monitoring volumetric pressures across the network-seldom enter such social spaces, which they perceive as dangerous. This is a tautological designation that is assumed based on neighborhoods' heterogeneous spatial configurations, residents' connections with informal economies (albeit poorly understood) and, in the case of Hermosillo, deeply rooted ethnic stereotypes. Such biases fundamentally shape how planning and provisioning work, as the real composition and characteristics of assumed-to-be unruly and illegal spaces and their residents are misunderstood. The label of informality continues to influence social and political processes; it mediates the development of infrastructure and patterns of service provision, in addition to treatment of residents. Residents of informal colonias and old barrios that increasingly rely on locally-developed connections are blamed for the pressure their households place on the already overtaxed water provision system, as well as for flooding issues due to system malfunctions and topographical features of these neighborhoods.

Both citizens and government officials shape the political terrain of water infrastructure negotiations. Government officials' promises of service connection, or their decisions to not service certain areas based on presumed criminality or unlawful status, are political actions that frame the terms of citizen engagement. We draw attention to residential interventions into their own water and sanitation service provisioning because this is central to the organization of life in the margins. Interventions, and residents' perceptions of alternatives, also reveal citizenship clashes in the modern city. The framework of insurgent citizenship brings into focus the political dimensions of individual actions undertaken in the peripheries of urban infrastructure (Holston 2007, 2009). Through everyday domestic tasks, such as materially constructing dwellings in urban infrastructural peripheries, residents are reconfiguring their relationship to the city. Urban residents' political 
action is not limited to collective mobilizations in central arenas like the civic square or the sidewalk outside the utilities office. As our article demonstrates, citizen political action is also found in mundane engagements with infrastructure. Decentralized alternatives like composting toilets or rainwater harvesting and direct interventions in city grids via autonomous repairs or informal connections are everyday political actions with resilience and survival at their core. Understanding such practices can help highlight the issues with both approaches and inform both policy and practice.

\section{Conclusion}

In sum, while there are no simple solutions for rapid urbanization exacerbating entrenched resource governance challenges, new approaches are required to confront what scholars call "wicked problems" (Austin 2010; Conklin 2005; Lach et al. 2005; Rittel and Webber 1973). Such wicked problems are complex and entangled, where no straightforward or "right" answers exist (ibid). To begin approaching these issues with social equity and environmental sustainability in mind, communities must be fundamentally involved in the research process. Put differently, we cannot understand the nature of such challenges without examining the problems from multiple perspectives, particularly from the margins where shortcomings and potential alternatives are most visible. We should be healthily skeptical of the cure-all potential of both large and "informal" infrastructure options, yet also open to both under the right conditions. There are no prescribed solutions. Cities are constantly reworking social, ecological, and technical relationships - these must be understood empirically; their realities and resource management challenges cannot be predetermined.

Praxis informed by theorizing relations to infrastructure and nature can lead to a different sense of critical consciousness that may enable more informed infrastructure decisions. This requires understanding the everyday realities and interactions with infrastructure with collaborators, the people who live and negotiate these realities on a daily basis. A political ecology-informed praxis can guide this critical inquiry process, offering the repetitive pedaling that continues to move research forward, often toward unexpected destinations. The theoretical orientation of this praxis maintains ecological dynamics in cyclical reflection and action (Loftus 2013). Collaborating with residents living on the urban fringes re-centers local perspectives that are typically excluded from or misrepresented in urban development programs. In our own processes of praxis, we broadened and sharpened our research through iterative action and reflection with local people, ecologies, and socio-technical relationships.

Research oriented toward understanding and exploring problems with research participants strives not necessarily for a solution but instead to be educational and to reframe the problematic with multiple actors. Through interactions with research collaborators, we developed more nuanced understandings of the neighborhoods we worked in: how they define urban water problems and view emergent solutions or barriers. Our positionalities as applied anthropologists framed our approach and analysis of pressing socioenvironmental problems. We strove to maintain a research orientation in line with community expressed needs and interests. We both sought to situate this partial understanding of grounded infrastructural realities within analysis of historical and contemporary government policies and practices in order to constructively demonstrate the disjuncture between the two. While state laws and policies often push for homogeneity, urban realities are contextually based - topography, ecology, history, economic development, and other processes of social differentiation shape infrastructure solutions. Urban planning must account for context and history in order to arrive at viable and pragmatic infrastructural solutions.

Our approach presents a form of applied anthropology that is explicitly normative, while grounding political ecology in ethnography and reflective analysis. We examined relationships between large and small technologies and perspectives on these issues from the margins. Infrastructural changes are not necessarily complete metabolic processes, as sometimes portrayed in the literature, but instead are fragments of ongoing government projects and residents' self-organizing responses. As researchers, if we want to inform viable urban water management and sanitation solutions, we must first look closely at the pipes from different angles, asking questions with research collaborators informed by local needs and reflective practice. 


\section{References}

Agua, Comisión Nacional. 2010. Guía sobre la participación privada en la prestación de los servicios de agua y saneamiento. Semarnat.

Anand, N. 2012. Municipal disconnect: on abject water and its urban infrastructures. Ethnography 13(4): 487-509.

Anand, N. 2011. Pressure: the polytechnics of water supply in Mumbai. Cultural Anthropology 26(4): 542563.

Austin, D.E. 2004. Partnerships, not projects! Improving the environment through collaborative research and action. Human Organization 63(4): 419-430.

Austin, D.E. 2010. Confronting environmental challenges on the US-Mexico border: long term community based research and community service learning in a binational partnership. Journal of Community Practice 18(2/3): 361-395.

Baba, M. L. 2000. Theories of practice in anthropology: a critical appraisal. In C.E. Hill and M.L. Baba (eds.) The unity of theory and practice in anthropology: rebuilding a fractured synthesis (NAPA Bulletin). Hoboken: Wiley-Blackwell. Pp 17-44.

Bannister, J. 2014. Are you Wittfogel or against him? Geophilosophy, hydrosociality, and the state. Geoforum 57: 205-214.

Barkin, D., and D. Klooster. 2006. Estrategias de la gestion del agua urbana. In D. Barkin (ed.) La gestión del agua urbana en México: retos, debates, y bienestar. Guadalajara: Universidad de Guadalajara.

Bebbington, A., D.H. Bebbington, J. Bury, J. Lingan, J.P. Muñoz, and M Scurrah. 2008. Mining and social movements: struggles over livelihood and rural territorial development in the Andes. World Development 36(12): 2888-2905.

Boelens, R., B. Duarte, R. Manosalvas, P. Mena, T. Roa Avendaño, and J. Vera. 2012. Contested territories: water rights and the struggles over indigenous livelihoods. International Indigenous Policy Journal 3(3): 1-15.

Boelens, R., I. Gentes, A. Guevara Gil, and O. Urteaga Corvetto. 2006. Agua, identidad y legislación especial. In D.H. Getches and J.A. Guevara Gil (eds.) Agua y derecho: políticas hídricas, derechos consuetudinarios e identidades locales. Lima: Instituto de Estudios Peruanos. Pp 131-188.

Cahill, C. 2007. The personal is political: developing new subjectivities through participatory action research. Gender, Place and Culture 14(3): 267-292.

Castro, J.E. 2004. Urban water and the politics of citizenship: the case of the Mexico City Metropolitan Area during the 1980s and 1990s. Environment and Planning A 36(2): 327-346.

Castro, J.E. 2007. Poverty and citizenship: sociological perspectives on water services and public-private participation. Geoforum 38: 756-771.

Conklin, J. 2006. Dialogue mapping: creating shared understanding of wicked problems. West Sussex, UK: Wiley and Sons.

de Vos, H., R. Boelens, and R. Bustamante. 2006. Formal law and local water control in the andean region: a fiercely contested field. International Journal of Water Resources Development 22(1): 37-48.

Dourish, P., and G. Bell. 2007. The infrastructure of experience and the experience of infrastructure: meaning and structure in everyday encounters with space. Environment and Planning B: Planning and Design 34(3): 414-430.

Eddy, E.M., and W.L. Partridge (eds.) 1987. Applied anthropology in America. New York: Columbia University Press.

Escobar, A. 1997. Anthropology and development. International Social Science Journal 49(154): 497-515.

Freire, P. 1972. Cultural action for freedom. New York: Penguin Books.

Gandy, M. 2004. Rethinking urban metabolism: water, space and the modern city. City 8(3): 363-379.

García, M. 2012. Personal communication on August 25. 
Haraway, D. 1988. Situated knowledges: the science question in feminism and the privilege of partial perspective. Feminist Studies 14(3): 575-599.

Hernández, J. 2012. Personal communication on September 27.

Heynen, N., M. Kaika, and E. Swyngedouw. 2006. Urban political ecology. In Heynen, N., M. Kaika, and E. Swyngedouw (eds.) In the nature of cities: urban political ecology and the politics of urban metabolism. New York: Routledge. Pp 1-19.

Hill, C.E. 2000. Strategic issues for rebuilding a theory and practice synthesis. In C.E. Hill and M.L. Baba (eds.) The unity of theory and practice in anthropology: rebuilding a fractured synthesis (NAPA Bulletin). Hoboken: Wiley-Blackwell. Pp 1-16.

Holston, J. 2007. Insurgent citizenship: Disjunctions of democracy and modernity in Brazil. Princeton, New Jersey: Princeton University Press.

Holston, J. 2009. Insurgent citizenship in an era of global urban peripheries. City \& Society 21(2): 245-267.

INEGI. 2010. Mexico en cifras: Informacion general, por entidad federativa y municipio. Instituto Nacional de Estadistica y Geografia. [accessed March 1 2015] http://www3.inegi.org.mx/sistemas/mexicocifras

Ingram, H.M., and N.R. Laney. 1995. Divided waters: bridging the US-Mexico border. Tucson: University of Arizona Press.

Johnston, B.R. 2003. The political ecology of water: an introduction. Capitalism Nature Socialism 14(3): 7390.

Kaika, M. 2005. City of flows: modernity, nature and the city. New York: Routledge.

Kelly-Richards, S.H., Leon Niebla, Y., Espinoza Ruelas, A., Verdugo Vazquez, E., and J.A. Baturoni. 2013. Water management and alternatives in a Mexican border city. Paper presented at Society for Applied Anthropology. Denver, CO. March 22, 2013.

Kelly-Richards, S. H., and J. M. Banister. In Press. A state of suspended animation: urban sanitation and water access in Nogales, Sonora. Political Geography

Lach, D. et al. 2005. Taming the waters: strategies to domesticate the wicked problems of water resource management. International Journal of Water 3(1): 1-17.

Lansing, J.S. 2007. Priests and programmers: technologies of power in the engineered landscape of Bali. Princeton: Princeton University Press.

Lassiter, L.E. 2005. The Chicago guide to collaborative ethnography. Chicago: University of Chicago Press.

Loftus, A. 2006. Reification and the dictatorship of the water meter. Antipode: a Radical Journal of Geography 38(5): 1023-1045.

Loftus, A. 2012. Everyday environmentalism: creating an urban political ecology. Minneapolis: University of Minnesota Press.

Loftus, A. 2013. Gramsci, nature, and the philosophy of praxis. In M. Ekers, G. Hart, K. Stefan, and A. Loftus (eds.) Gramsci: space, nature, politics. Hoboken: Wiley-Blackwell. Pp 178-196.

Loftus, A., and D.A. MacDonald. 2001. Of liquid dreams: a political ecology of water privatization in Buenos Aires. Environment \& Urbanization 13(2): 179-199.

López, C. 2012. Personal communication on August 25.

Meehan, K. 2013. Disciplining de facto development: water theft and hydrosocial order in Tijuana. Environment and Planning D: Society and Space 31: 319-336.

Mehta, L. 2003. Contexts and constructions of water scarcity. Economic and Political Weekly 38(48): 50665072.

Morehouse, B.J., R.H. Carter, and T.W. Sprouse. 2000. Implications of sustained drought for transboundary water management in Nogales, Arizona, and Nogales, Sonora. Natural Resources Journal 40: 783817.

Partridge, W.L. 1987. Toward a theory of practice. In E.M. Eddy and W.L. Partridge (eds.) Applied anthropology in America. New York: Columbia University Press. Pp 211-236. 
Peloso, M., and C. Morinville. 2014. 'Chasing for water': everyday practices of water access in peri-urban Ashaiman, Ghana. Water Alternatives 7(1): 121-139.

Perreault, T. 2005. State restructuring and the scale politics of rural water governance in Bolivia. Environment and Planning A 37(2): 263 - 284.

Perreault, T. 2008. Custom and contradiction: rural water governance and the politics of usos y costumbres in Bolivia's irrigators' movement. Annals of the Association of American Geographers 98(4): 834-854.

Perreault, T. 2014. Corrientes, colonialismos y contradicciones: repensando los raíces y trayectorias de la ecología política. Presentation, Congreso Latinoanericano de Ecologia Politica. Santiago de Chile.

Pineda-Pablos, N. 1999. Urban water policy in Mexico: municipalization and privatization of water services. Ph.D. dissertation. Austin, USA: University of Texas.

Pineda-Pablos, N. 2002. La política urbana de agua potable en México: del centralismo y los subsidios a la municipalización, la autosuficiencia y la privatización. Región y Sociedad XIV(24): 41-69.

Pineda-Pablos, N. 2006. Las tarifas y la autosuficiencia financier, la equidad y la conservación del agua: un studio comparative de las tarifas urbanas de agua potable en Sonora. In N. Pineda-Pablos (ed.) La busqueda de la tarifa justa. Mexico: El Colegio de Sonora. Pp 115-128.

Prichard, A.H., and C.A. Scott. 2014. Interbasin water transfers at the US-Mexico border city of Nogales, Sonora: implications for aquifers and water security. International Journal of Water Resources Development 30(1): 135-151.

Prichard, A.H., Scott, C.A., Vandervoet, P., and S. Megdal. 2010. Drought and urbanization: water supply challenges of Nogales, Sonora. Arizona Hydrological Society Symposium. Tucson, AZ.

Radonic, L. 2015. Environmental violence, water rights, and (un) due process in Northwestern Mexico. Latin American Perspectives 42(5): 27-47.

Robbins, P. 2012 . Political ecology: a critical introduction. Hoboken: Wiley-Blackwell.

Rodriguez, V. 1997. Decentralization in Mexico: from reforma municipal to solidaridad to nuevo federalismo. Boulder: Westview Press.

Rylko-Bauer, B., M. Singer, and J. van Willigen. 2006. Reclaiming applied anthropology: its past, present, and future. American Anthropologist 108(1): 178-190.

Salazar Adams, A. and N. Pineda-Pablos. 2010. Escenarios de demanda y políticas para la administración del agua potable en México: el caso de Hermosillo, Sonora. Región y Sociedad 22(47): 105-122.

Saxton, D. 2015. Ethnographic movement methods: anthropology takes on the pesticide industry. Journal of Political Ecology 22: 368-388.

Scott, J.C. 1998. Seeing like a state: how certain schemes to improve the human condition have failed. New Haven: Yale University Press.

Scott, C.A. and N. Pineda-Pablos. 2011. Innovating resource regimes: water, wastewater, and the institutional dynamics of urban hydraulic reach in northwest Mexico. Geoforum 42(4): 439-450.

Swyngedouw, E. 1997. Power, nature, and the city: the conquest of water and the political ecology of urbanization in Guayaquil, Ecuador: 1880-1990. Environment and Planning A 29(2): 311-332.

Swyngedouw, E. 2004. Social power and the urbanisation of water. Oxford: Oxford University Press.

Swyngedouw, E. 2005. Dispossessing $\mathrm{H}_{2} \mathrm{O}$ : the contested terrain of water privatization. Capitalism, Nature, Socialism 16(1): 81-98.

Swyngedouw, E. 2006. Circulations and metabolisms: (hybrid) natures and (cyborg) cities. Science and Culture 15: 105-121.

Van Willigen, J. 2002. Applied anthropology: an introduction. Westport Bergin \& Garvey.

Varady, R.G., and B. Morehouse. 2004. Cuanto cuesta?: development and water in Ambos Nogales and the upper San Pedro Basin. In K. Kopinak (ed.) The social costs of industrial growth in northern Mexico. San Diego: Center for US-Mexican Studies, UCSD. Pp 205-248.

Velez, Marisela. 2013. Personal communication on November 10. 
Walker, P.A. 2007. Political ecology: where is the politics? Progress in Human Geography 31(3): 363-369.

Whiteford, S., and R. Melville. 2002. Protecting a sacred gift: water and social change in Mexico. La Jolla: University of California Press.

Wilder, M., C.S. Scott, N. Pineda Pablos, R.G. Varady, G.M. Garfin, and J. McEvoy. 2010. Adapting across boundaries: climate change, social learning, and resilience in the U.S.-Mexico border region. Annals of the Association of American Geographers 100(4): 917-928.

Wilder, M., and P. Romero Lankao. 2006. Paradoxes of decentralization: water reform and social implications in Mexico. World Development 34(11): 1977-1995.

Wilder, M., and J. Slack. 2010. Ambos Nogales: water, vulnerability, and institutional complexity. Arizona Hydrological Society Meeting. Tucson, Arizona.

Wilder, M., C.S. Scott, N. Pineda Pablos, R.G. Varady, and G. Garfin. 2011. Urban water vulnerability and institutional challenges in Ambos Nogales: moving forward from vulnerability to adaptation: climate change, drought, and water demand in the urbanizing southwestern United States and northern Mexico. Working Papers on Climate Change and Water Resources No. 1. Tucson: Udall Center for Studies in Public Policy. 